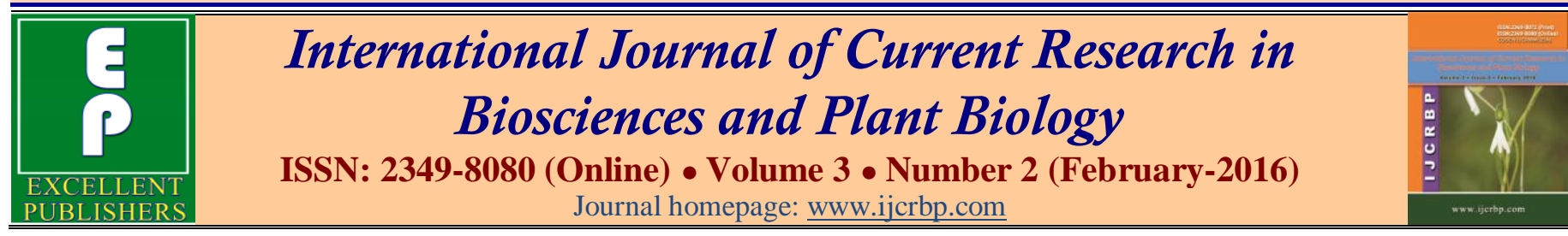

Original Research Article

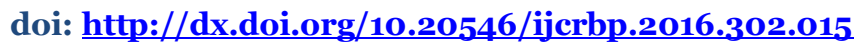

\title{
Floristic Composition of Weeds in Coconut (Cocos nucifera L.) Plantations of Sivagangai District, Tamil Nadu, Southern India
}

\section{Sevugaperumal Shanmugam ${ }^{*}$, Raju Nagaraj², Sethuri Balamurugan¹, Bose Raja1, Kuppu Rajendran ${ }^{1}$ and Natchimuthu Karmegam²}

${ }^{1}$ Post Graduate and Research Department of Botany, Thiagarajar College, Madurai - 625 oo9, Tamil Nadu, India

${ }^{2}$ Department of Botany, Government Arts College, Salem - 636 oo7, Tamil Nadu, India

*Corresponding author.

\begin{abstract}
A bstract
A study was conducted to find out the weed floristic composition in coconut (Cocos nucifera L.) plantations of Sivagangai district in Tamil Nadu. Totally 92 weed species (75 species of dicots, 16 species of monocots and 1 species of Pteridophyte) of 81 genera belonging to 37 families were recorded in the study area. A total of 36 angiospermic families were found in the study area. Among them 33 families belonged to dicots and 3 to monocots. Poaceae (11 species) was found as dominant family followed by Amaranthaceae (7 species) and Convolvulaceae and Euphorbiaceae (each of 6 species). 19 families were found with single species.
\end{abstract}

\section{Article Info}

Accepted: 01 February 2016

Available Online:06 February 2016

\section{Keywords}

Coconut plantations

Sivagangai district

Weed flora

\section{Introduction}

Weeds are unwanted plants in the cropland that compete with other plants for water, nutrients and space. These plants may be found growing on agricultural fields and gardens (Ngugi et al., 1978; Stephen, 1982; Casas et al., 1996). Weeds also act as hosts for pests and diseases. The abundance or distribution of weed species in a cropped field varies due to the nature of the crops, cultural practices cropping pattern/system, soil type, moisture availability, location and season. Weed species form a component of agro-biodiversity, playing a part in the ecology of natural enemies as in harbouring and supporting many beneficial arthropod species that suppress pest populations consequently improving crop yields (Richerdson et al., 1992).

Extensive literature is available on weed flora dynamics in field crops (Moyer et al., 1989; Fuente et al., 1999; Derksen et al., 2002), as well as on weed flora in palms grown as plantations (Gopinathan Nair and Chami, 1963; Thomas and Abraham, 1996), data palm (Abd-El-Ghani,
1998; El-Halawany, 2001), areca nut (Sahapurmath et al., 2003), peach palm (Bogants and Aguero, 2003; Souza et al., 2003) and grape fields (Selvakumar and Shanmugam, 2010). There has also been an increasing effort on the study of weeds relating to systematic studies (Tiwrai, 1981; Holzner and Immonen, 1982; Barua, 1992; Singh et al., 1994; Ara et al., 1995; Tan et al, 2000; Isaiarasu and Ganesan, 2005), ecological studies (Pandya, 1989; Blumenthal and Jordan, 2001; Suarez et al., 2001), medicinal (Oudhia, 1999; Oudhia, 1999a; Khan et al., 2004; Pandey and Rai, 2005; Jeeva et al., 2006), and food values (Hajra and Chakraborty, 1981; Selvakumar and Shanmugam, 2009; Shanmugam et al., 2011).

Knowledge of weeds flora enables one to use the required herbicide and formulate other suitable management strategies. It is also useful to exploiting abundance weeds as a crop cover or pasture and for other economic uses (Sit et al., 2007). According to Derksen et al. (2002), the study of weed dynamics is essential to formulate a management strategy for the cropping 
system. Hence, the present study has been carried out to document the weed plants grown under Coconut (Cocos nucifera L.) plantations of Sivagangai District in Tamil Nadu.

\section{Materials and methods}

The survey was conducted in coconut (Cocos nucifera L.) growing areas of Sivagangai district in Tamil Nadu, just after the rainy season. The entire area of Sivagangai district lies between $9^{\circ} 30^{\prime}-10^{\circ} 30^{\prime} \mathrm{N}$ latitude and $77^{\circ} 00^{\prime}$ $-78^{\circ} 30^{\prime}$ E longitude. The altitude of the study area is about $102 \mathrm{~m}$ (334 feet) above mean sea level. The district is spread over an area of about 4189 sq. $\mathrm{km}$ and is bounded on the North and Northeast by Pudukkottai district, on the Southeast and South by Ramanathapuram District, on the Southwest by Virudhunagar district and on the West by Madurai district. The district receives an annual rainfall is about $635-1019 \mathrm{~mm}$. The maximum and minimum temperature varies between $20^{\circ}$ and $40^{\circ} \mathrm{C}$. The study area has high population density and large area of agricultural land. This study includes major coconut cultivating areas from Sivagangai district. Flora of Tamil
Nadu Carnatic (Matthew, 1983-1986) was used to ascertain the nomenclature of weed species recorded.

\section{Results and discussion}

A total of 92 weeds distributed among 81 genera of 37 families (91 weed species of 80 genera belonging to 36 families of angiosperms and a species of the genus Marsilia belonging to 1 family of Pteridophyte) were recorded in the study area (Table 1). Among the 91 species distributed among 36 families of angiosperms, 75 species of 33 families belonged to dicots and 16 species of 3 families belonged to monocots. The percentage of monocots and dicots is about $17.392 \%$ and $81.522 \%$ respectively. Totally $99.014 \%$ of angiosperms and $1.086 \%$ of pteridophytes were recorded in the study area (Table 2). In the case of dicots the maximum number of weeds ( 7 species) was recorded for the family Amaranthaceae. In the case of monocots the maximum number of weeds $(11$ species $)$ was recorded for the family Poaceae. A total of 18 families of dicots and one family of monocots were recorded only one species (Table 2).

Table 1. Weed species recorded in the study area with their family and local name.

\begin{tabular}{|c|c|c|c|}
\hline S. No. & Botanical Name & Family & Local Name \\
\hline \multicolumn{4}{|c|}{ Dicotyledons } \\
\hline 1. & Abutilon indicum $\mathrm{L}$. & Malvaceae & Thuthi \\
\hline 2. & Acalypha indica $\mathrm{L}$. & Euphorbiaceae & Kuppaimeni \\
\hline 3. & Achyranthes aspera L. & Amaranthaceae & Naayuruvi \\
\hline 4. & Aerva lanata (L.) Juss. & Amaranthaceae & Sirukanpeelai \\
\hline 5 & Alternanthera sessilis DC. & Amaranthaceae & Ponnaanganni \\
\hline 6. & Alysicarpus vaginalis (L.) DC. & Fabaceae & Kaakkattaan \\
\hline 7. & Amaranthus gralcizans L. & Amaranthaceae & Sirukeerai \\
\hline 8. & Amaranthus spinosus L. & Amaranthaceae & Mullikkeerai \\
\hline 9. & Amaranthus tristis Roxb. & Amaranthaceae & Thandangeerai \\
\hline 10. & Argemone mexicana $\mathrm{L}$. & Papaveraceae & Birammathandu \\
\hline 11. & Aristolochia indica $\mathrm{L}$ & Aristolochiaceae & Preumarundhu \\
\hline 12. & Asystasia gangetica (L.) T. Anderson & Acanthaceae & Medday keerai \\
\hline 13. & Azima tetracantha Lam. & Salvadoraceae & Sangilai \\
\hline 14. & Boerhavia diffusa L. & Nyctanginaceae & Padarmookirattai \\
\hline 15. & Boerhavia erecta $\mathrm{L}$. & Nyctanginaceae & Mookirattai \\
\hline 16. & Calotropis gigantea (L). R.Br. & Asclepiadaceae & Yerukkam \\
\hline 17. & Cardiospermum halicacabum L. & Sapindaceae & Mudakkathaan \\
\hline 18. & Citrullus colocynthis (L.) Schrader. & Cucurbitaceae & Kumattikkaai \\
\hline 19. & Cleome gynandra L. & Capparidaceae & Nallavelai \\
\hline 20. & Cleome viscosa $\mathrm{L}$. & Capparidaceae & Naaikkadukhu \\
\hline 21. & Clitoria ternatea $\mathrm{L}$. & Fabaceae & Sanguppoo \\
\hline 22. & Coccinia grandis (L.) Voigt. & Cucurbitaceae & Kovai \\
\hline 23. & Cocculus hirsutus (L.) Diels. & Menispermaceae & Kaattukkodi \\
\hline 24. & Corchorus aestuans L. & Tiliaceae & Karikkeerai \\
\hline 25. & Croton bonplandianus Baillon & Euphorbiaceae & Yeliaamanakku \\
\hline 26. & Cyphostemma setosum (Roxb.) Alston & Vitaceae & Pullinaranai \\
\hline 27. & Datura metel L. & Solanaceae & Oomathai \\
\hline 28. & Desmodium gangeticum (L.) DC. & Fabaceae & Pulladi \\
\hline
\end{tabular}




\begin{tabular}{|c|c|c|c|}
\hline S. No. & Botanical Name & Family & Local Name \\
\hline 29. & Desmodium triflorum (L.) DC. & Fabaceae & Sirupulladi \\
\hline 30. & Eclipta prostrata (L.) L.Mant. & Asteraceae & Karisalaanganni \\
\hline 31. & Enicostemma axillare (Lam.) A. Raynal. & Gentianaceae & Vellarugu \\
\hline 32. & Euphorbia hirta L. & Euphorbiaceae & Ammaan pacharisi \\
\hline 33. & Evolvulus alsinoides $\mathrm{L}$. & Convolvulaceae & Vishnukarandhi \\
\hline 34. & Glinus lotoides L. & Aizoaceae & Siruseruppadai \\
\hline 35. & Hibiscus vitifolius $\mathrm{L}$. & Malvaceae & Aattuparuthi \\
\hline 36. & Hybanthes ennaespermus L. & Violaceae & Oridhazh thaamarai \\
\hline 37. & Hygrophila auriculata (Schum) Heine. & Acanthaceae & Neermulli \\
\hline 38. & Indoneesiella echioides (L.) Sreemadh. & Acanthaceae & Koburandhaangi \\
\hline 39. & Ipomoea aquatica Forssk. & Convolvulaceae & Veelaikkeerai \\
\hline 40. & Ipomoea pes-tigridis $\mathrm{L}$. & Convolvulaceae & Poonaikkeerai \\
\hline 41. & Ipomoea obscura (L.) Ker Gawler. & Convolvulaceae & Siruthaalikkodi \\
\hline 42. & Leucas aspera (Willd) Link. & Lamiaceae & Thumbai \\
\hline 43. & Melochia corchorifolia $\mathrm{L}$. & Sterculiaceae & Yennaichedi \\
\hline 44. & Merremia emarginata Burm.f. & Convolvulaceae & Elikaadhukeerai \\
\hline 45. & Merremia tridentata $(\mathrm{L}$.) Hallier & Convolvulaceae & Mudhiyaar koondhal \\
\hline 46. & Mimosa pudica $\mathrm{L}$. & Mimosaceae & Thottaalsurungi \\
\hline 47. & Mukia maderaspatana (L.) M. Roem. & Cucurbitaceae & Musumusukkai \\
\hline 48. & Ocimum sanctum $\mathrm{L}$. & Lamiaceae & Thulasi \\
\hline 49. & Oldenlandia umbellata $\mathrm{L}$. & Rubiaceae & Muthakkaasu \\
\hline 50. & Parthenium hysterophorus L. & Asteraceae & Mookuthipoochedi \\
\hline 51. & Passiflora foetida $\mathrm{L}$. & Passifloraceae & Mupparisavalli \\
\hline 52. & Pedalium murex $\mathrm{L}$. & Pedaliaceae & Yaanai nerungil \\
\hline 53. & Pergularia daemia (Forssk.) Chior. & Asclepiadaceae & Velipparuthi \\
\hline 54. & Phaseolus vulgaris L. & Fabaceae & Miinnikkaai \\
\hline 55. & Phyllanthus amarus Schum \& Thom. & Euphorbiaceae & Keelaanelli \\
\hline 56. & Physalis minima $\mathrm{L}$. & Solanaceae & Sodakku thakkaali \\
\hline 57. & Polygonum plebeium R.Br. & Polygonaceae & Kanganichedi \\
\hline 58. & Portulaca oleracea L. & Portulacaceae & Paruppukkeerai \\
\hline 59. & Pupalia atropurpurea (Lam.) Moq. & Amaranthaceae & Sunnaambukkeerai \\
\hline 60. & Rungia repens (L.) Nees & Acanthaceae & Kudakham \\
\hline 61. & Sida caprinifolia $\mathrm{L}$. & Malvaceae & Pazhambaasi \\
\hline 62. & Sida cordifolia $\mathrm{L}$. & Malvaceae & Nilathuthi \\
\hline 63. & Solanum nigrum L. & Solanaceae & Manthakkaali \\
\hline 64. & Spermacoce hispida L. & Rubiaceae & Naathaisoori \\
\hline 65. & Stachytarpheta indica auct.non (L.) Vahl & Verbenaceae & Seemainaayuruvi \\
\hline 66. & Synedrella nodiflora (L.) Gaertner & Asteraceae & Kaattukolai \\
\hline 67. & Tephrosia purpurea Pers. & Fabaceae & Kozhunji \\
\hline 68. & Tinospora cordifolia Miers. & Menispermaceae & Seendhil \\
\hline 69. & Tragia involucrata $\mathrm{L}$. & Euphorbiaceae & Sendhatti \\
\hline 70. & Trianthema portulacastrum L. & Aizoaceae & Vellaichaaranai \\
\hline 71. & Tribulus terrestris L. & Zygophyllaceae & Nerungil \\
\hline 72. & Trichodesma indicum (L.) R.Br. & Boraginaceae & Kavizhthumbai \\
\hline 73. & Tridax procumbens $\mathrm{L}$. & Asteraceae & Thaathaapoochedi \\
\hline 74. & Vernonia cinerea $\mathrm{L}$. & Asteraceae & Sirudhevi sengeluneer \\
\hline 75. & Zaleya decandra (L.) Burm.f. & Aizoaceae & Sirusaaranai \\
\hline \multicolumn{4}{|c|}{ Monocotyledons } \\
\hline 76. & Andropogon pumilus Roxb. & Poaceae & Kokkuvaaippull \\
\hline 77. & Aristida hystrix L.f. & Poaceae & Kaandhaarippull \\
\hline 78. & Chloris barbata Sw. & Poaceae & Kodaippull \\
\hline 79. & Chrysopogan acciculatus $\mathrm{L}$. & Poaceae & Sorrkkappull \\
\hline 80. & Commelina benghalensis $\mathrm{L}$. & Commelinaceae & Thengaaipoochedi \\
\hline 81. & Cynodon dactylon (L.) Pers. & Poaceae & Arugambullu \\
\hline 82. & Cyperus corymbosus Rottb. & Cyperaceae & Seemaikorai \\
\hline 83. & Cyperus rotundus $\mathrm{L}$. & Cyperaceae & Korai \\
\hline 84. & Dactyloctenium aegypticum (L.) P. Beauv. & Poaceae & Sevalkaalpull \\
\hline
\end{tabular}




\begin{tabular}{clll}
\hline S. No. & Botanical Name & Family & Local Name \\
\hline 85. & Dicanthium annulatum (L.) P. Beauv. & Poaceae & Silandhippull \\
86. & Eragrostis pilosa (L.) P. Beauv. & Poaceae & Poopull \\
87. & Fimbristylis cymosa R.Br. & Cyperaceae & Kothuppullu \\
88. & Kyllinga monocephala Rottb. & Cyperaceae & Mallikorai \\
89. & Panicum repens L. & Poaceae & Thenippull \\
$90 . \quad$ Paspalum conjugatum L. & Poaceae & Naaivaragu \\
91. & Setaria italica (L.) P. Beauv. & Poaceae & Ottuppullu \\
Pteridophytes & & Marsiliaceae \\
92. & Marsilea quadrifolia L. & & Aarakkeerai \\
\hline
\end{tabular}

Table 2. Number of weed species in different families recorded.

\begin{tabular}{|c|c|}
\hline Family & Number of weed species \\
\hline \multicolumn{2}{|l|}{ Dicotyledons } \\
\hline Acanthaceae & 4 \\
\hline Aizoaceae & 3 \\
\hline Amaranthaceae & 7 \\
\hline Aristolochiaceae & 1 \\
\hline Asclepiadaceae & 2 \\
\hline Asteraceae & 5 \\
\hline Boraginaceae & 1 \\
\hline Capparidaceae & 2 \\
\hline Convolvulaceae & 6 \\
\hline Cucurbitaceae & 3 \\
\hline Euphorbiaceae & 6 \\
\hline Fabaceae & 5 \\
\hline Gentianaceae & 1 \\
\hline Lamiaceae & 1 \\
\hline Malvaceae & 4 \\
\hline Menispermaceae & 2 \\
\hline Mimosaceae & 1 \\
\hline Nyctanginaceae & 2 \\
\hline Papaveraceae & 1 \\
\hline Passifloraceae & 1 \\
\hline Pedaliaceae & 1 \\
\hline Polygonaceae & 1 \\
\hline Portulacaceae & 1 \\
\hline Rubiaceae & 2 \\
\hline Salvadoraceae & 1 \\
\hline Sapindaceae & 1 \\
\hline Solanaceae & 3 \\
\hline Sterculiaceae & 1 \\
\hline Tiliaceae & 1 \\
\hline Verbenaceae & 1 \\
\hline Violaceae & 1 \\
\hline Vitaceae & 1 \\
\hline Zygophyllaceae & 1 \\
\hline \multicolumn{2}{|l|}{ Monocotyledons } \\
\hline Commelinaceae & 1 \\
\hline Cyperaceae & 4 \\
\hline Poaceae & 11 \\
\hline \multicolumn{2}{|l|}{ Pteridophytes } \\
\hline Marsiliaceae & 1 \\
\hline
\end{tabular}

As many as 33 families of dicots, 3 families of monocots and 1 member of Pteridophytes were noticed during the study. Members of both dicots and monocots were found in all the locations studied. Among monocots, only Commelinaceae, Cyperaceae and Poaceae were noticed in the study area. Dicots dominant over the monocots in all the locations studied. Gopinathan Nair and Chami (1963) found dicotyledons to be dominant in coconut gardens. Commelinaceae, Cyperaceae and Poaceae are the major monocot families and Asteraceae, Fabaceae and Rubiaceae are the predominant dicot families seen in coconut gardens. They also concluded that the weeds of the families Cyperaceae and Poaceae are the most troublesome. In this study also the weeds of the families Cyperaceae and Poaceae are the most predominant. But in the case of dicots Amaranthaceae ( 7 species) was found as dominant family followed by Convolvulaceae and Euphorbiaceae (each of 6 species).

Sit et al. (2007) reported that 17 families of dicots, three families of monocots (Poaceae, Cyperaceae and Araceae) and four members of pteridophytes were noticed in palm gardens including coconut plantations in Plains of Eastern Himalayan region of West Bengal. The present study revealed that only one species of pteridophyte was recorded from coconut plantations in Sivagangai district of Tamil Nadu.

Souza et al. (2003) found the plants of Poaceae, Euphorbiaceae, Fabaceae, Cyperaceae and Verbenaceae to be predominant weeds in Cupuacu and peach palm gardens. Tahira et al. (2010) studied the weed flora of Curcuma longa fields in Kasur district of Pakistan and 14 weed species belonging to eight angiosperm families (Asteraceae, Brassicaceae, Chenopodiaceae, Euphorbiaceae, Malvaceae, Poaceae, Ranunculaceae and Solanaceae).

The present investigation reveals that the prevalence of dicot weed species was higher in all conditions under study than that of the monocots. Restriction of some weed species to particular areas supports the fact that 
they require special conditions for growth, whereas the presence of some weeds in all the study areas shows that they can grow under varied light conditions.

\section{Conclusions}

While making culture operations in Coconut plantations, these plants are treated as weeds and destroyed. This may lead these species ultimately to the disappearance in future. Therefore, conservation strategies must be carried out on these species. As per the available literatures about weeds, these are having nutritional and medicinal values. So, attention should also be made on proper utilization of these plants.

\section{Conflict of interest statement}

Authors declare that they have no conflict of interest.

\section{Acknowledgement}

The authors are cordially grateful to the people inhabiting in different localities of Sivagangai district because of their kind support and co-operation in the field works. One of us (SS) is thankful to University Grants Commission, New Delhi for financial Assistance under Rajiv Gandhi National Fellowship Scheme, 2008.

\section{References}

Abd-El-Ghani, M. M., 1998. Weed community of date palm orchards in the Feiran Oasis (South Sinai, Egypt). Fragm. Florist. Geobot. 43, 257-271.

Ara, S., Naqshi, A.R., Dar, G.M., 1995. Weed flora of cultivated fields of Gurais valley, Kashmir. J. Econ. Taxon. Bot. 19(2), 293-302.

Baruah, I., 1992. Systematic studies of the Angiosperms of Kamrup district, Assam. Ph. D., Thesis, Gauhati University, India.

Blumenthal, D., Jordan, N., 2001. Weeds in field margins: a spatially explicit simulation analysis of Canada thistle population dynamics. Weed Sci. 49, 509-519.

Bogantes, A., Aguero, R., 2003. Weed dynamics and control in peach palm (Bactris gasileps) for palm hearts. Agron. Mesoamericana. 149, 41-49.

Derksen, A.D., Andersen, L.R., Blackshaw, E.R., Maxwell, B., 2002. Weed dynamics and management strategies for cropping systems in the Northern Great Plains. Agron. J. 3, 174-185.

El-Halawany, E.F., 2001. Flora and vegetation of date palm orchards in the north eastern part of the Nile delta, Egypt. Egypt. J. Bot. 41, 41-64.

Fuente, E. B., Saurez, S.A., Ghersa, C.M., Leon, R.J.C., 1999. Soyabean weed communities Relationship with cultural history and crop yield. Agron. J. 91, 234-241.
Gopinathan Nair, R., Chami, P.A., 1963. A survey of weeds in the fields of coconut research station, Kasaragod. Indian Coconut J. XVII, 40-47.

Hajra, P.K., Chakraborty, P., 1981. A Survey of wild plants sold in the Lall market of Gangtok. J. Ind. For. 4(3), 217220.

Holzner, W., Immonen, R., 1982. Europe: an overview of weed flora and vegetation. Geobot. 2, 203-226.

Isaiarasu, L., Ganesan, R., 2005. Weed flora observed in a mulberry garden near Sivakasi, Tamil Nadu. Bionotes. 7(2), 64-65.

Jeeva, S., Kiruba, S., Mishra, B.P., Venugopal, N., Dhas, S.S.M., Regini, G.S., Kingston, C., Kavitha, A., Sukumaran, S., Raj, A.D.S., Laloo, R.C., 2006. Weeds of Kanyakumari district and their value in rural life. Indian J. Trad. Knowl. 5(4), 501-509.

Katewa, S.S., 2003. Contribution of some wild food plants from forestry to the diet of tribals of Southern Rajasthan. Indian Fores. 129(9), 1117-1130.

Khan, A.A., Khan, S., Singh, M.P., 2004. Weeds of Soybean (Glycine $\max$ (L.) Merr.) and their medicinal importance in Rewa Division, Madhya Pradesh, India. Ad. Plant Sci. 17(1), $67-69$.

Matthew, K.M., 1983-1986. Flora of Tamil Nadu Carnatic. Rapinat Herbarium, St. Joseph's College, Tiruchirapalli.

Moyer, J. R., Owenya, Z.J., Kibuwa, S.P., 1989. Weed population and agronomic practices at wheat farms on the Hanang plains of Tanzania. Trop. J. Pest Manage. 35, 2629.

Pandey, R.K., Rai, S.P., 2005. Ethnobotanical studies of less known uses of weeds as medicinal plants of Bhojpur District (Bihar). Environ. Ecol. 23(1), 121-124.

Pandya, S.M., 1989. Dynamics of crop-weed associations of some agroecosystems of Saurashtra (Gujrat)-an ecological perspective. Final Report, Dept. of Biosciences, Saurashtra University, Rajkot, India.

Sahapurmath, G. B., Srivanna, H., Girisha, H.V., 2003. Studies on weed intensity in existing areca based agro forestry models. Karnataka J. Agric. Sci. 16, 260-264.

Selvakumar, P., Shanmugam, S., 2009. Edible weeds in coconut (Cocos nucifera L.) plantations of Sivagangai district of Tamil Nadu. In: Ramachandran, V.S. (Ed.), Proceedings of National Seminar on Recent Trends in the Conservation and Utilization of Under Utilized Wild Edible Plants (CUWEP - 2009). Department of Botany, School of Life Sciences, Bharathiar University, Coimbatore, Tamil Nadu, India. pp. 200-207.

Selvakumar, P., Shanmugam, S., 2010. Flora of weeds in Grape (Vitis vinifera L.) fields of Theni district of Tamil Nadu, India. In: National Level Seminar on Emerging Trends in Plant Biotechnology. Post Graduate and Research Department of Plant Biology and Plant Biotechnology, Government Arts College, Coimbatore, Tamil Nadu. Abs. No. 49, pp. 87.

Shanmugam, S., Kamaladasan, N., Arunraja, T., Sakthivel, B., Rajendran, K., 2011. Edible weeds in Grape (Vitis vinefera $\mathrm{L}$.) fields of Theni district in Tamil Nadu, India. Int. J. Forest Usuf. Manage. 12(1), 112-117.

Sharma. P.D., 1998. Ecology and Environment, Rastogi Publication, Meerut. 
Singh, R.D., Singha, B.K., Sud, R.K., Tamang, M.B., Chakraborty, D.N., 1994. Weed flora in tea plantations of Himachal Pradesh. J. Econ. Taxon. Bot. 18(2), 399-404.

Sit, A.K., Pattacharya, M., Sarkar, B., Arunachalam, V., 2007. Weed floristic composition in palm gardens in plains of Eastern Himalayan regions of West Bengal. Curr. Sci. 92(10), 1434-1439.

Souza, L. S. A., Silva, J.F., Souza, M.D.B., 2003. Floristic composition of weeds in agro-systems of Cupuacu (Theobroma grandiflorum) and peach palm (Bactris gasipaes). Planta-Daninha. 21, 249-255.

Susana A. Suarez, Elba B. de la Fuente, Claudio M. Ghersa and Rolando J.C. Leon, 2001. Weed Community as an indicator of summer crop yield and site quality. Agron. J. 93, 524-530.

Tahira, J.J. Nawaz Khan, S., Suliman, R., Anwar, W., 2010. Weed flora of Curcuma longa fields of district Kasur, Pakistan. Pak. J. Weed Sci. Res. 16(2), 241-246.

Tan N.T., Son, N. H., Trung, H.M., Auld, A.B., Hetherington, S.D., 2000. Weed flora of water rice in the Red River Delta, Vietnam. Int. J. Pest Manage. 46(3), 285-287.

Thomas, C.G., Abraham, C.T., 1996. Weeds of coconut gardens in the central zone of Kerala. Indian Coconut J. $26,8-10$.

Tiwari, J.P., 1981. The major winter weeds in Sagar Division of Madhya Pradesh. Indian J. Weed Sci. 14(1), 37-42.

\section{How to cite this article:}

Shanmugam, S., Nagaraj, R., Balamurugan, S., Raja, B., Rajendran, K., Karmegam, N., 2016. Floristic composition of weeds in coconut (Cocos nucifera L.) plantations of Sivagangai district, Tamil Nadu, southern India. Int. J. Curr. Res. Biosci. Plant Biol. 3(2), 121-126. doi: http://dx.doi.org/10.20546/ijcrbp.2016.302.015 